\title{
SOSIALISASI PEMBATASAN PELAKSANAAN KEGIATAN MASYARAKAT (PPKM) MIKRO DI KELURAHAN BAH KAPUL
}

\author{
Ulung Napitu ${ }^{1}$ Corry $^{2}$, Marhaeni K.D. Matondang ${ }^{3}$ \\ ${ }^{1,2)}$ Program Studi Pendidikan Sejarah, FKIP, Universitas Simalungun \\ ${ }^{3)}$ Program Studi Pendidikan Bahasa Inggris, FKIP, Universitas Simalungun \\ e-mail: ulungnapitu2018@gmail.com
}

\begin{abstract}
Abstrak
Pengabdian masyarakat ini bertujuan untuk memberikan pemahaman yang mendalam tentang bahaya penyebaran Covid-19 dan meningkatkan kesadaran masyarakat untuk mematuhi protokol kesehatan, social distancing, new normal, dan pelaksanaan pemberlakuan pembatasan kegiatan masyarakat (PPKM) Mikro bagi seluruh masyarakat, perkantoran, dunia usaha, dunia industri, aktivitas keagamaan dan berbagai aktivitas kemasyarakatan lainnya sampai pada tingkat desa/kelurahan di kecamatan Siantar Sitalasari. Masalah yang ditemukan ditengah masyarakat sampai saat ini masih tingginya masyarakat yang terpapar Covid-19 padahal pemerintah telah melaksanakan berbagai kebijakan mulai dari pemberlakuan lock down, pembatasan skala besar, new normal, social distancing, memberlakukan secara ketat protokol kesehatan, memberlakukan Pemberlakuan Pembatasan Kegiatan Masyarakat (PPKM) yang ditindaklanjuti dengan pemberlakuan PPKM Mikro namun hasilnya belum dapat menurunkan secara signifikan penyebaran Covid-19. Untuk mensosialisasikan materi pengabdian masyarakat tersebut kepada masyarakat digunakan metode ceramah dan tanya jawab kepada seluruh warga masyarakat kelurahan Bah Kapul Kecamatan Siantar Sitalasari yang berlangsung selama 90 menit. Hasil dari sosialisasi tersebut semakin meningkat pemahaman masyarakat tentang penyebaran dan bahaya Covid-19 serta kesadaran masyarakat untuk melindungi dirinya dalam melakukan berbagai aktivitas sehari-hari di kantor, pasar, rumah ibadah, dan berbagai kegiatan lainnya.
\end{abstract}

Kata kunci : Covid-19, Pembatasan, Kegiatan, Masyarakat, Mikro

\begin{abstract}
This Community Service aims to provide a deep understanding about the dangers of COVID 19 spread and increase public awareness to comply with health protocols, social distancing, new normal, and implementation of micro restriction, Pembatasan Pelaksanaan Kegiatan Masyarakat Mikro (PPKM) Mikro, for all business, industrial, religious, and other community activities to the sub-district kelurahan) level in the Siantar Sitalasari district. The problem is, the number of people infected with COVID-19 is still high even though the government has enforced policies, such as lockdown, large-scale restrictions, new normal, social distancing, including PPKM which extended to PPKM Mikro. However, this has not been able to reduce the spread of COVID-19 significantly.

To disseminate this community service material, the methods used are lecture and Q\&A session with all residents of the Bah Kapul Sub-district, in Siantar Sitalasari district, which lasted in 90 minutes. The result is increasing in people's understanding of the COVID-19 spread and its dangers, as well as awareness, to protect themselves in carrying out daily activities in offices, markets, or worship places.
\end{abstract}

Keywords: Covid-19, Discussion, Activities, Society, Micro

\section{PENDAHULUAN}

Sampai saat ini warga dunia yang terjangkit Covid-19 bertambah setiap hari. Berdasarkan data KOMPAS.com, jumlah pasien terinfeksi corona di dunia, hingga 01 Maret $2021 \pm 114$ juta kasus. Data yang positif Covid-19, berjumlah ratusan ribu pasien yang meninggal dunia dan 64,4 juta dinyatakan sembuh. Perkembangan Covid-19 di Indonesia, sampai saat ini masih meningkat jumlahnya. Akibat peningkatan kasus Covid-19 pemerintah melaksanakan berbagai kebijakan berupa PSBB, lock down, pembatasan dalam skala terbatas, social distancing, new normal, 
mentaati protokol kesehatan dan kebijakan lainnya (Blair, 2017; Rundolph, 2020; Suryahadi, 2020). Kebijakan ini membawa dampak semakin terpuruknya kondisi ekonomi dan dampak lainnya yang bersifat multidimensi. Menyadari kebijakan tersebut tidak dapat mengatasi pandemi Covid-19, pemerintah mulai pertengahan Februari 2021 melaksanakan kebijakan yang disebut dengan Pemberlakuan Pembatasan Kegiatan Masyarakat (PPKM) Mikro serta mengupayakan vaksin massal kepada seluruh warga masyarakat secara bertahap di seluruh Indonesia (Peraturan Mendagri No.41 2020). Kegiatan pengabdian masyarakat ini bertujuan untuk:

a. Mengatasi penyebaran Covid-19 yang sampai saat ini masih terus meningkat, pada tingkat desa dan kelurahan.

b. Mengoptimalkan pembatasan kegiatan masyarakat dalam berbagai aspek kehidupan sampai kepada tingkat desa/kelurahan dengan pemberlakuan pembatasan kegiatan masyarakat (PPKM) Mikro.

c. Meningkatkan kesadaran masyarakat untuk melaksanakan dan menaati protokol kesehatan, social distancing serta pembatasan kegiatan masyarakat (PPKM) Mikro.

\section{METODE}

Kegiatan untuk mensosialisasikan dan menyampaikan pembatasan pelaksanaan kegiatan masyarakat (PPKM) Mikro pada masyarakat kelurahan Bah Kapul dilaksanakan secara tatap muka dengan menggunakan metode ceramah bervariasi yang berlangsung selama 90 menit. Para narasumber secara bergantian menyampaikan materi pengabdian masyarakat secara langsung kepada masyarakat dan narasumber memberikan kesempatan untuk melaksanakan tanya-jawab kepada masyarakat tentang materi yang disampaikan (Vredenbregt, 1984). Pemberian kesempatan tanya-jawab kepada masyarakat bertujuan untuk meningkatkan pemahaman masyarakat tentang bahaya penyebaran Covid-19 dan berbagai kegiatan yang harus ditaati dan dilakukan pada masa pembatasan pelaksanaan kegiatan masyarakat (PPKM) Mikro.

\section{HASIL DAN PEMBAHASAN \\ 1. PPKM Mikro}

Dalam mengendalikan penyebaran COVID-19, pemerintah memutuskan untuk melaksanakan pemberlakuan pembatasan kegiatan masyarakat (PPKM). Pemberlakuan pembatasan kegiatan masyarakat (PPKM) Mikro dilakukan secara terbatas di beberapa Kota/Kabupaten bertujuan untuk mengurangi penyebaran Covid-19 sampai pada tingkat kelurahan/desa dan mengupayakan peningkatan perekonomian masyarakat Indonesia secara bertahap (SK Mendagri No.41 Tahun 2020; SK Menteri Perhubungan No. 18 Tahun 2020).

Pemberlakuan pembatasan kegiatan masyarakat (PPKM) Mikro dilakukan atas pertimbangan karena sejumlah daerah masih memiliki resiko sangat tinggi dan menjadi episentrum peningkatan kasus COVID-19. Daerah ini utamanya di ibu kota provinsi dan daerah kabupaten/kota lainnya, di Indonesia termasuk Provinsi Sumatera Utara dan Kota Pematangsiantar.

PPKM Mikro bukan pelarangan kegiatan tetapi pengaturan kembali pemberlakuan pembatasan beberapa kegiatan masyarakat dengan tujuan agar kegiatan tersebut tidak menjadi klaster baru dan sumber penyebab terjadinya peningkatan kasus positif COVID-19 sampai pada tingkat kelurahan/desa di seluruh Indonesia (Sampurno, 2020).

Pemberlakuan PPKM Mikro diatur berdasarkan Instruksi Menteri Dalam Negeri Nomor 01 Tahun 2021 tanggal 6 Januari dan diberlakukan sejak tanggal 11-25 Januari dan diperpanjang sampai bulan Maret 2021. Sebelum dilakukan PPKM Mikro telah dilaksanakan PPKM untuk mengurangi penyebaran Covid-19. PPKM mengatur sejumlah hal di dalam kehidupan masyarakat yaitu:

1. Membatasi tempat kerja dengan WFH 75 persen dengan melakukan prokes secara ketat.

2. Kegiatan belajar mengajar secara daring (online).

3. Sektor esensial yang berkaitan dengan kebutuhan pokok masyarakat tetap beroperasi 100 persen dengan pengaturan jam operasional, kapasitas, dan menjaga protokol kesehatan secara ketat. 
4. Melakukan pembatasan terhadap jam buka dari kegiatan-kegiatan di pusat perbelanjaan sampai pukul 19.00 waktu setempat. Makan dan minum di tempat makan atau restoran maksimal 25 persen. Pemesanan makanan melalui take away atau delivery tetap diizinkan.

5. Mengizinkan kegiatan konstruksi beroperasi 100 persen dengan penerapan protokol kesehatan yang ketat.

6. Mengizinkan tempat ibadah melakukan pembatasan kapasitas sebesar 50 persen dengan penerapan protokol kesehatan yang lebih ketat.

7. Fasilitas umum dan kegiatan sosial budaya dihentikan sementara.

8. Pengaturan kapasitas dan jam operasional moda transportasi (Keputusan Gubernur Sumut No. 188.44/125/KPTS/2021).

Gubernur di seluruh Indonesia termasuk Gubernur Sumatera Utara, dapat menetapkan Kota/Kabupaten lain di wilayahnya untuk dilakukan pemberlakuan pembatasan (PPKM) mikro, dengan mempertimbangkan empat parameter yang telah ditetapkan yaitu tingkat kematian, tingkat kesembuhan, tingkat kasus aktif dan tingkat keterisian rumah sakit, serta pertimbangan lain untuk memperkuat upaya pengendalian COVID-19.

Untuk mengoptimalkan pembatasan penyebaran Covid-19 di seluruh Indonesia pemerintah memberlakukan kebijakan pembatasan kegiatan masyarakat (PPKM) Mikro. Istilah yang digunakan adalah Pemberlakuan Pembatasan Kegiatan Masyarakat (PPKM) skala mikro atau PPKM mikro. Setelah dua jilid PPKM di Pulau Jawa dan Bali dinilai tak efektif menekan laju penyebaran Covid-19, Sejak 09 Februari 2021 pemerintah memberlakukan PPKM mikro di sejumlah wilayah di 7 provinsi. Wilayah pemberlakuan PPKM dan PPKM mikro sama seperti sebelumnya, berlaku di 7 provinsi dan berbagai provinsi di Indonesia, termasuk Provinsi Sumatera Utara (Keputusan Gubernur Sumut No. 188.44/125/KPTS/2021).

Adapun ketentuan pada PPKM Mikro adalah sebagai berikut:

1. Pada PPKM berbasis mikro, ada ketentuan pembentukan posko penanganan Covid-19 di tingkat desa dan kelurahan dalam rangka pengendalian Covid-19.

2. Pada PPKM jilid I, jam operasional restoran dan pusat perbelanjaan dibatasi hingga pukul 19.00, pada PPKM jilid II, jam operasional lebih longgar, hingga pukul 20.00 WIB. Aturan pada PPKM mikro lebih longgar lagi, di mana jam operasional mal/pusat perbelanjaan diizinkan hingga pukul 21.00 WIB.

3. Pada PPKM, pembatasan di perkantoran adalah 25 persen work from office, dan 75 persen work from home. Sementara, pada PPKM mikro, aturannya lebih longgar, dengan 50 persen work from office dan 50 persen work from home (Republika, 2021; Kompas, 2021; VOI.ID, 2021).

Pemberlakuan PPKM Mikro adalah sampai ke tingkat RT/RW. PPKM Mikro diusung sebagai respons atas pelaksanaan PPKM di Jawa-Bali yang dinilai tidak berjalan efektif. Berdasarkan Instruksi Menteri Dalam Negeri Nomor 3 Tahun 2021, PPKM Mikro diterapkan di 7 provinsi yang ada di Jawa-Bali yaitu Banten, DKI Jakarta, Jawa Barat, Jawa Tengah, DIY, Jawa Timur, Bali dan Provinsi lainnya di Indonesia.

Aturan yang diberlakukan dalam PPKM Mikro didasarkan pada zonasi Covid-19 suatu daerah, apakah masuk zona hijau, kuning, oranye, atau merah. Pada zona merah, PPKM dilakukan hingga tingkat RT. Mulai dari penutupan rumah ibadah, tempat bermain anak, dan tempat umum lain yang sifatnya non esensial. Masyarakat dilarang berkumpul lebih dari 3 orang. Mobilitas warga untuk keluar masuk wilayah RT dibatasi maksimal pada pukul 20.00. Dan seluruh kegiatan kemasyarakatan di lingkungan RT yang menumbulkan kerumunan harus ditiadakan (Kompas, 2021). Skema pemberlakuan PPKM Mikro dapat dilihat pada isi gambar berikut : 


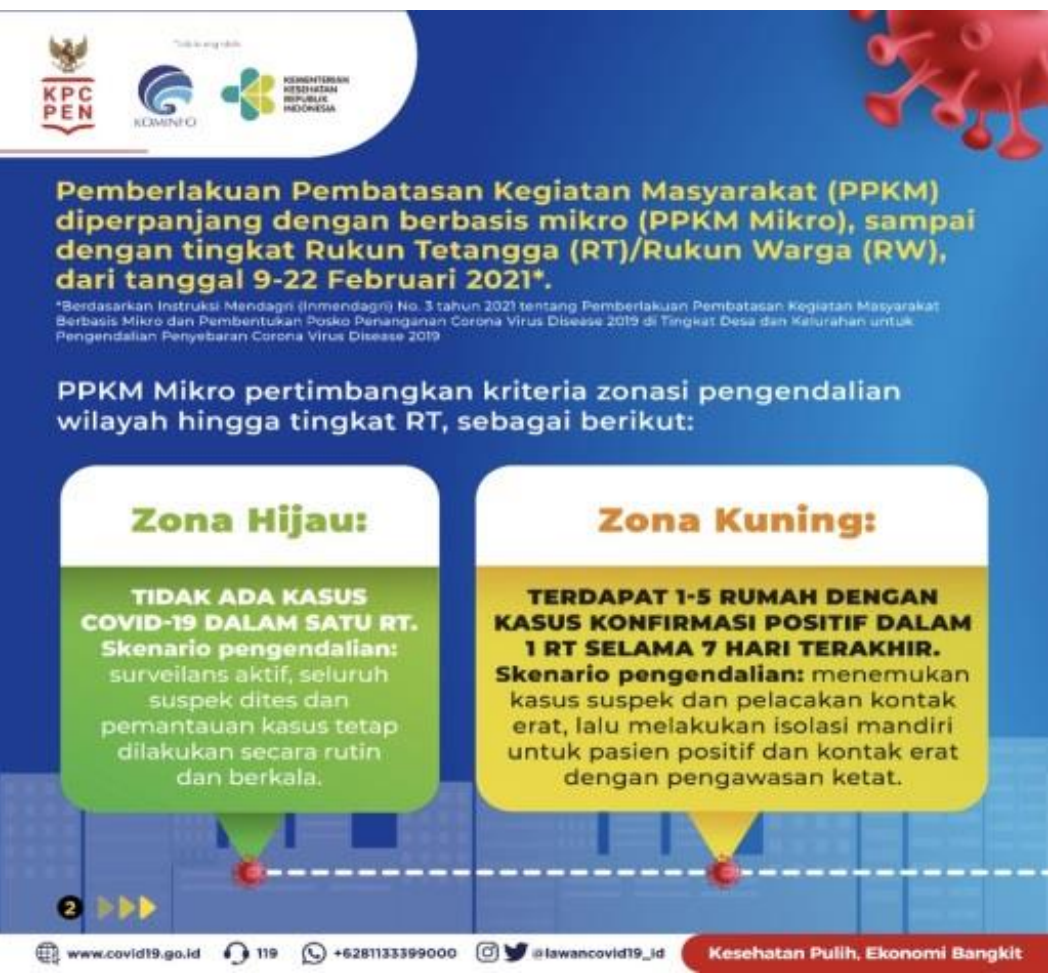

Sumber : Kompas, 2021

Gambar 1. Zona Di Dalam Aturan PPKM Mikro

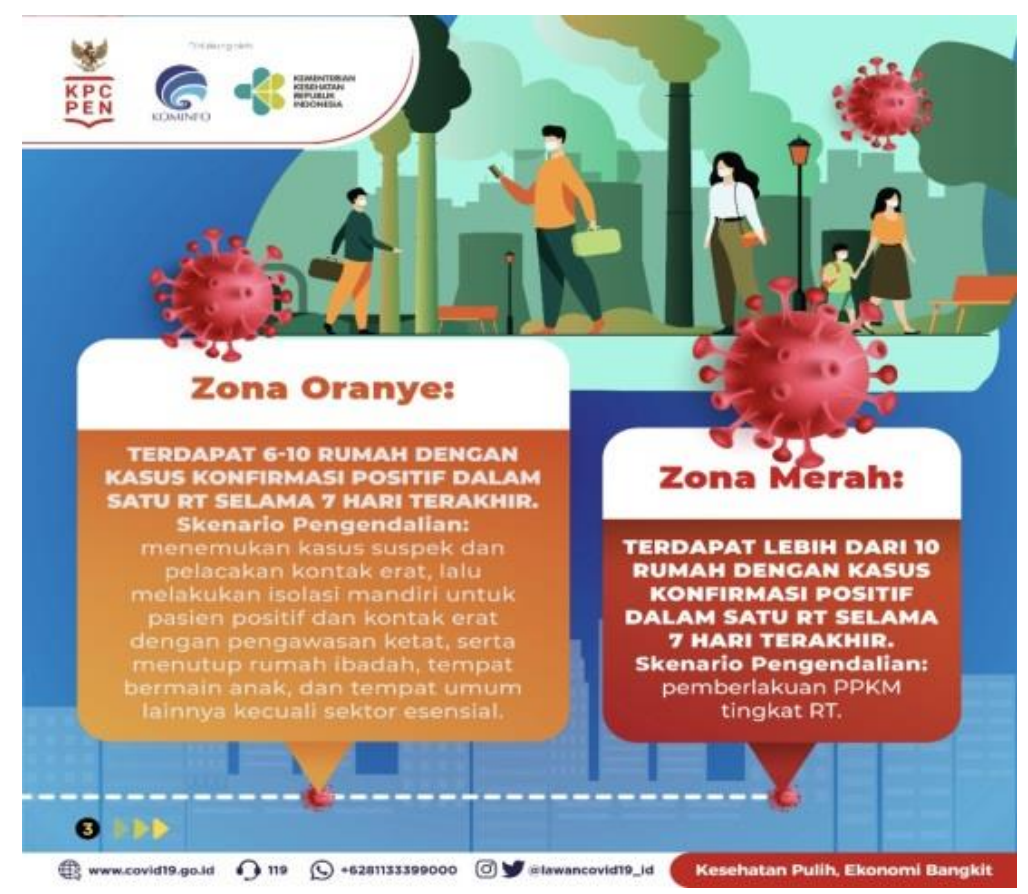

Sumber: Republika, 2021

Gambar 2. Zona Di Dalam Aturan PPKM Mikro 


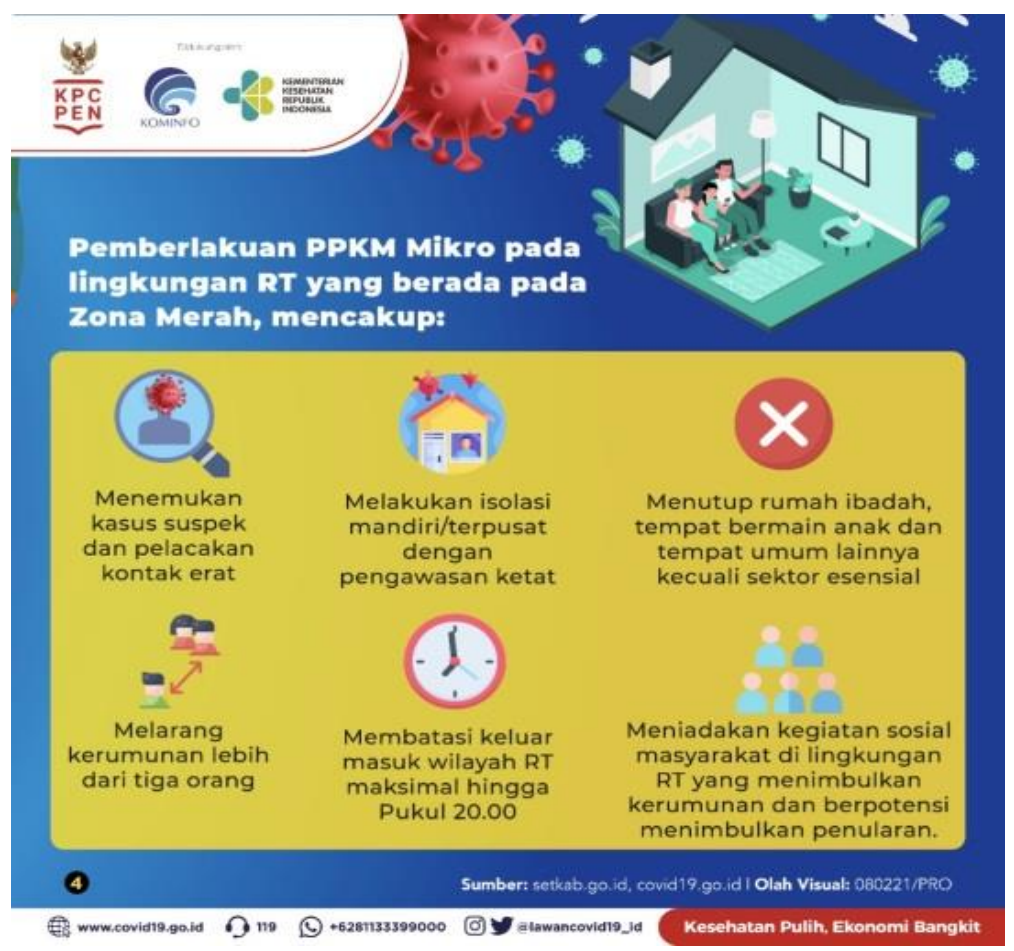

Sumber: Kompas, 2021

Gambar 3. Pemberlakuan PPKM Mikro Pada Zona Merah

Pelaksanaan PPKM mikro di daerah zona merah dilakukan berdasarkan koordinasi lintas sektor di wilayah itu mulai RT, RW, kepala desa, Babinsa, Bhabinkamtibmas, Satpol PP, Tim PKK, Posyandu, Dasawisma, para tokoh masyarakat, termasuk tenaga kesehatan. Di wilayah non zona merah, PPKM akan tetap dilakukan dengan aturan penerapan bekerja dari rumah sebesar 50 persen, pelaksanaan belajar-mengajar daring (Peraturan Mendagri No.41 2020).

Di daerah-daerah, sektor esensial tetap diperbolehkan beroperasi 100 persen dengan pembatasan jam, kapasitas, dan pengetatan protokol kesehatan. Restoran hanya boleh menerima 50 persen kuota untuk makan/minum di tempat, begitu juga dengan tempat ibadah hanya bisa diisi 50 persen kuota.

Pusat perbelanjaan/mall maksimal buka hingga pukul 21.00, semua fasilitas umum dan kegiatan sosial budaya yang menimbulkan kerumunan dihentikan sementara, transportasi umum dibatasi kapasitas dan operasionalnya, lalu kegiatan konstruksi diizinkan beroperasi penuh dengan pengetatan protokol.

Untuk memastikan PPKM Mikro berjalan dengan optimal, dibentuk posko di tingkat desa/kelurahan yang diawasi oleh posko di tingkat kecamatan. Posko tingkat desa/kelurahan melakukan fungsi pencegahan, penanganan, pembinaan, dan pendukung pelaksanaan penanganan Covid-19 yang diketuai oleh kepala desa dibantu perangkat dan mitra desa/kelurahan. Mereka berkoordinasi dengan Satgas Covid-19 yang ada di tingkat atasnya atau TNI/Polri (Peraturan Mendagri No.41 2020).

Pemerintah Provinsi (Pemprov) Sumatra Utara (Sumut) menerapkan pemberlakuan pembatasan kegiatan masyarakat (PPKM) mikro di enam kabupaten kota. Langkah ini ditempuh karena angka penyebaran Covid-19 di enam daerah tersebut cukup tinggi. Keenam daerah yang menerapkan PPKM mikro yakni, Kota Medan, Binjai, Pematangsiantar, Kabupaten Deliserdang, Langkat dan Simalungun (Keputusan Gubernur Sumut No. 188.44/125/KPTS/2021).

Berdasarkan instruksi gubernur, penerapan PPKM mikro pada enam daerah berlangsung mulai 9 hingga 22 Maret 2021. Kegiatan masyarakat di luar rumah dan tempat-tempat usaha dibatasi hingga pukul 21.00 WIB. Pegawai perkantoran masih harus bekerja dari rumah dengan kuota 50 persen dan kegiatan belajar sekolah tetap secara daring. 
Agar kebijakan PPKM Mikro tersebut optimal diperlukan memfasilitasi tempat kerja yang aman dan sehat, dengan cara:

1. Memastikan kebersihan tempat kerja

2. Menyediakan lebih banyak sarana cuci tangan dengan sabun dan air mengalir.

3. Memberikan petunjuk lokasi sarana cuci tangan

4. Memasang poster edukasi cara mencuci tangan yang benar

5. Menyediakan handsanitizer dengan konsentrasi alkohol minimal 70\% di tempat-tempat yang diperlukan, seperti pintu masuk, ruang rapat, pintu lift, dan lain-lain.

6. Menerapkan physical distancing dalam semua aktivitas kerja. Pengaturan jarak antar pekerja minimal 1 meter pada setiap aktivitas kerja, dengan mengadakan pengaturan meja kerja atau workstation, pengaturan kursi saat di kantin, dan lain-lain (Keputusan Gubernur Sumut No. 188.44/125/KPTS/2021).

Upayakan untuk selalu mencari informasi terbaru dan terpercaya tentang perkembangan Pandemi Covid-19, untuk melindungi diri dan keluarga. Berikut ini rekomendasi dari Kementerian Kesehatan RI agar terhindar dari Covid-19 selama di Tempat Kerja :

1. Saat tiba, segera mencuci tangan dengan sabun dan air mengalir.

2. Gunakan siku untuk membuka pintu dan menekan tombol lift.

3. Tidak berkerumun dan menjaga jarak di lift dengan posisi saling membelakangi.

4. Untuk sementara tidak menggunakan absensi finger print.

5. Bersihkan meja/area kerja dengan desinfektan.

6. Upayakan tidak sering menyentuh fasilitas/peralatan yang dipakai bersama di area kerja, gunakan handsanitizer.

7. Tetap menjaga jarak dengan rekan kerja minimal 1 meter.

8. Usahakan aliran udara dan sinar matahari masuk ke ruang kerja.

9. Biasakan tidak berjabat tangan.

10. Masker tetap digunakan.

11. Selalu menerapkan perilaku hidup bersih dan sehat ditempat kerja (Peraturan Mendagri No.41 2020).

\section{Adaptasi Kebiasaan Di Sektor Jasa Dan Perdagangan Pada Masa Pemberlakuan PPKM Mikro}

Untuk mengoptimalkan pelaksanaan PPKM Mikro, protokol kesehatan pada masa New Normal harus tetap dilaksanakan secara ketat dengan cara beradaptasi pada berbagai sektor kegiatan. Aturan Adaptasi Kebiasaan Baru bagi penyelenggara sektor jasa dan perdagangan diatur dalam Surat Edaran Menteri Kesehatan Nomor HK.02.01/MENKES/335/2020 tentang Protokol Pencegahan Penularan Covid-19 di Tempat Kerja Sektor Jasa dan Perdagangan (Area Publik) dalam Mendukung Keberlangsungan Usaha.

Berikut beberapa Adaptasi Kebiasaan Baru pada sektor Jasa dan Perdagangan yang ditetapkan Menteri Kesehatan dan harus ditaati pada masa pemberlakuan PPKM Mikro yaitu:

a. Bagi penyelenggara/pelaku usaha sektor jasa dan perdagangan

1. Melakukan pembersihan dan disinfeksi secara berkala di area kerja dan area publik

2. Menyediakan fasilitas cuci tangan yang memadai dan mudah diakses oleh pekerja dan konsumen/pelaku usaha

3. Memastikan pekerja memahami perlindungan diri dari penularan Covid-19 dengan perilaku hidup bersih dan sehat (PHBS)

4. Pengecekan suhu badan bagi seluruh pekerja sebelum mulai bekerja dan konsumen atau pelaku usaha di pintu masuk. Pekerja dengan suhu $>37,30$ derajat Celcius setelah dua kali pemeriksaan dengan jarak lima menit, tidak diperkenankan masuk dan diminta untuk melakukan pemeriksaan kesehatan.

5. Mewajibkan pekerja dan pengunjung menggunakan masker

6. Melakukan pembatasan jarak fisik minimal 1 meter. 
7. Mencegah kerumunan (Peraturan Mendagri No.41 2020; Surat Edaran Menteri Kesehatan Nomor HK.02.01/MENKES/335/2020).

b. Bagi pekerja/konsumen, yang dapat dilakukan adalah :

1. Pastikan dalam kondisi sehat sebelum berangkat bekerja. Pekerja yangmengalami gejala seperti demam/batuk/pilek/sakit tenggorokan disarankanuntuk tidak masuk bekerja dan memeriksakan diri ke fasilitas pelayanankesehatan jika diperlukan.

2. Jaga kebersihan tangan dengan sering mencuci tangan dengan sabun danair mengalir, atau menggunakan handsanitizer.

3. Hindari tangan menyentuh area wajah seperti mata, hidung atau mulut.

4. Tetap memperhatikan jaga jarak/physical distancing minimal 1 meter saatberhadapan dengan pelaku usaha atau rekan kerja pada saat bertugas.

5. Menggunakan pakaian khusus kerja dan mengganti pakaian saat selesai bekerja.

6. Gunakan masker saat berangkat dan pulang dari tempat kerja serta selamaberada di tempat kerja.

7. Segera mandi dan berganti pakaian sebelum kontak dengan anggota keluarga di rumah. Bersihkan handphone, kacamata, tas, dan barang lainnyadengan cairan desinfektan (Peraturan Mendagri No.41 2020; Surat Edaran Menteri Kesehatan Nomor HK.02.01/MENKES/335/2020).

\section{c. Bagi Konsumen/Pelanggan}

1. Selalu menggunakan masker selama berada di area publik

2. Jaga kebersihan tangan dengan sering mencuci tangan dengan sabun danair mengalir atau menggunakan handsanitizer.

3. Hindari menyentuh area wajah seperti mata, hidung dan mulut.

4. Tetap memperhatikan jaga jarak/physical distancing minimal 1 meter dengan orang lain (Peraturan Mendagri No.41 2020; Surat Edaran Menteri Kesehatan Nomor HK.02.01/MENKES/335/2020).

Berbagai hal yang harus dipersiapkan untuk melakukan PPKM Mikro adalah mempersiapkan mental untuk menerima segala perubahan kebiasaan yang akan terjadi. Semua orang diminta berperilaku hidup sehat, social distancing dan melaksanakan protokol kesehatan. Protokol pencegahan itu di antaranya:

a. Selalu menggunakan masker jika bepergian ke luar rumah.

b. Memahami etika batuk.

c. Tidak ke luar rumah jika tak memiliki kepentingan mendesak.

d. Rajin mencuci tangan dengan air bersih mengalir dan sabun atau menggunakan hand sanitizer dengan kadar alkohol minimal $60 \%$.

e. Tidak bertukar barang dengan orang lain di tempat kerja, misalnya membawa piring, gelas, dan sendok sendiri.

f. Menjaga jarak dan menghindari kerumunan (Peraturan Mendagri No.41 2020; Surat Edaran Menteri Kesehatan Nomor HK.02.01/MENKES/335/2020).

\section{Kolaborasi Pemerintah dan Masyarakat Melalui Pelaksanaan PPKM Mikro}

Berbagai kebijakan untuk menghadapi pandemi Covid-19 sudah dilakukan yang menjadi pertanyaan, sampai kapan masyarakat dengan berbagai sektor kehidupannya harus hidup dalam masa ketidakpastian, ketidaknyamanan dan ketidakamanan akibat Covid-19. Mengingat saat ini belum ditemukan vaksin atau obat untuk penyembuhan korban yang terinfeksi Covid-19, para ahli kesehatan memprediksi pandemi Covid-19 masih akan berlangsung dalam waktu yang lama (WHO, 2020).

Kerentanan sosial menyebabkan ketahanan masyarakat (community resilience) mengalami guncangan (shock) akibat pandemi Covid-19. Ketahanan masyarakat berkaitan dengan kemampuan masyarakat untuk menggunakan sumber daya yang tersedia (seperti, teknologi, makanan, pekerjaan, dan rasa aman, nyaman) dalam memenuhi kebutuhan dasar dan 
menjalankan fungsi sosialnya. Kondisi saat ini justru menjadikan ketahanan masyarakat mengalami kerentanan sosial. Kerentanan sosial membuat produktivitas menurun, mata pencarian terganggu, dan munculnya gangguan kecemasan sosial di masyarakat (WHO, 2011).

Dampak kerentanan sosial menyebabkan sebagian masyarakat melakukan tiga tindakan yang saling terkait, yaitu tindakan apatis, tindakan irasional, dan tindakan kriminal. Tindakan apatis bisa kita lihat pada tindakan masyarakat yang tidak peduli dengan instruksi pemerintah untuk menjalankan protokol kesehatan. Tindakan irasional artinya, tidak sedikit masyarakat meyakini berbagai bahan obat dan metode pencegahan agar tidak terkena Covid-19 sekalipun belum ada bukti penelitian ilmiahnya, panic buying, berhutang ke rentenir, depresi, sucide dan perilaku maladaptif lainnya. Tindakan kriminal merupakan perilaku yang dikuatirkan terjadi akibat kerentanan sosial atas pandemi Covid-19 seperti pencurian, penjambretan, pencopetan, pemalakan, penjarahan, bahkan pembunuhan. Tindakan kriminal dilakukan karena sulitnya memenuhi kebutuhan akibat sulit mencari mata pencaharian, terjadi PHK, kondisi ekonomi, rendahnya daya beli masyarakat dan semakin rendahnya kohesi sosial. Untuk mempertahankan kelangsungan hidup bagi masyarakat yang tidak memiliki akses kapital dengan baik, maka jalan singkat yang beresiko dilakukannya berupa tindakan kriminal dan behavior social deviation (Romdiati, 2006; Sampurno, 2020; Suryahadi, 2020; Shuja, 2020).

Tiga tindakan dan beserta beberapa contohnya, hanya sebagian dari dampak kerentanan sosial yang terjadi dalam kehidupan masyarakat akibat pandemi Covid-19. Contoh kasus lain dapat kita amati bersama pada berbagai media dan realitas lingkungan kehidupan sosial yang cenderung menimbulkan kerawanan sosial.

Tidak berbeda jauh dengan pelanggaran pada masa PSBB, bahkan lebih tinggi tingkat pelanggarannya. Hal yang perlu dipertimbangkan oleh pemerintah saat ini dalam menerapkan pemberlakuan pembatasan kegiatan masyarakat (PPKM) Mikro, bahwa seluruh aktivitas kehidupan masyarakat harus sesuai protokol kesehatan dan pemerintah dalam pelaksanaan PPKM Mikro ini harus mengawasinya secara ketat. Program ini dapat berhasil secara efektif dan efisien tentunya harus di dukung dengan kesadaran masyarakat untuk melakukan ketentuan PPKM Mikro, social distancing dan protokol kesehatan serta kewaspadaan terhadap bahaya Covid-19. Apabila masyarakat dan pemerintah melaksanakan PPKM Mikro ini dengan penuh kesadaran dan ketaatan, diharapkan penyebaran wabah Covid-19 sampai tingkat desa/kelurahan akan semakin berkurang, pemulihan ekonomi akan dapat dilaksanakan secara berangsur-angsur dan kehidupan masyarakat akan kembali semakin baik/normal (Peraturan Mendagri No.41 2020; Surat Edaran Menteri Kesehatan Nomor HK.02.01/MENKES/335/2020; Keputusan Gubernur Sumut No. 188.44/125/KPTS/2021).

\section{SIMPULAN}

a. Pandemi Covid-19 telah ditangani oleh pemerintah melalui berbagai kebijaksanaan berupa lock down, PSBB, pembatasan dalam skala terbatas, social distancing, dan PPKM Mikro serta memberlakukan protokol kesehatan, namun saat ini belum dapat mengurangi korban Covid-19 di Indonesia termasuk di Kota Pematangsiantar.

b. Untuk memperbaiki kondisi ekonomi dan mengatasi berbagai kerawanan sosial pemerintah dan masyarakat secara terintegrasi berkolaborasi melaksanakan PPKM Mikro sampai tingkat desa/kelurahan.

c. Dalam pelaksanaan PPKM Mikro agar dapat berhasil secara maksimal pemerintah dan masyarakat serta stake holder harus bekerjasama secara sinergis, sehingga adaptasi kehidupan baru dapat terlaksana secara efektif dan efisien sampai pada tingkat desa/kelurahan.

d. Melaksanakan pemberlakuan pembatasan kegiatan masyarakat (PPKM) Mikro harus memedomani pola hidup sehat, sesuai dengan SK Menteri Kesehatan.

\section{SARAN}

1. Hendaknya seluruh lapisan masyarakat dan pemerintah dengan penuh kesadaran dan konsisten melaksanakan pemberlakuan pembatasan kegiatan masyarakat (PPKM) Mikro, 
protokol kesehatan dan kegiatan lainnya yang mendukung upaya mengatasi penyebaran Covid-19 di tengah keluarga, masyarakat, pekerjaan, dan aktivitas lainnya sampai tingkat desa/kelurahan.

2. Seluruh masyarakat seharusnya dalam melaksanakan pemberlakuan pembatasan kegiatan masyarakat (PPKM) Mikro tetap melaksanakan patuh social distancing dan protokol kesehatan sehingga penyebaran Covid-19 dapat ditekan di tengah masyarakat.

3. Seluruh masyarakat seharusnya membiasakan pola hidup sehat, teratur, bersih, mengkonsumsi asupan gizi yang seimbang dan menghindarkan diri dari berbagai tempat yang dianggap potensial dan massif sebagai penyebaran Covid-19.

\section{UCAPAN TERIMAKASIH}

Puji dan syukur kami panjatkan doa kepada Tuhan Yang Maha Esa karena berkat-Nya kami Dosen FKIP-USI dapat melaksanakan kegiatan pengabdian masyarakat dengan judul "Sosialisasi Pembatasan Pelaksanaan Kegiatan Masyarakat (PPKM) Mikro Di Kelurahan Bah Kapul" berlangsung dengan baik sesuai dengan yang direncanakan. Kegiatan pengabdian masyarakat ini dimaksudkan untuk meningkatkan pemahaman dan kesadaran masyarakat tentang perlunya melaksanakan protokol kesehatan secara ketat dan ditindaklanjuti dengan pembatasan kegiatan masyarakat dengan skala mikro. Kegiatan sosialisasi pembatasan pelaksanaan kegiatan masyarakat (PPKM) Mikro ini dapat berlangsung dengan baik berkat adanya dukungan dan bantuan dari seluruh aparat kelurahan dan masyarakat yang bermukim di kelurahan Bah Kapul. Oleh sebab itu, pada kesempatan ini kami mengucapkan terimakasih kepada seluruh aparat kelurahan dan seluruh masyarakat yang telah berkenan mengikuti sosialisasi tersebut. Semoga kegiatan ini bermanfaat bagi seluruh masyarakat kelurahan Bah Kapul sehingga wabah Covid-19 dapat dibatasi dan roda ekonomi masyarakat dapat berlangsung semakin normal. Sekian dan terimakasih.

\section{DAFTAR PUSTAKA}

Blair, R. A., Morse, B. S., \& Tsai, L. L. (2017). Public health and public trust: Survey evidence from the Ebola Virus Disease epidemic in Liberia. Social Science \& Medicine, 89-97.

Randolph, H. E., \& Barreiro, L. B. (2020). Herd Immunity: Understanding COVID-19. Immunity, 737-741.

Peraturan Menteri Perhubungan No.41/2020. (2020). Perubahan Atas Peraturan Menteri Perhubungan Nomor PM 18 Tahun 2020 Tentang Pengendalian Transportasi Dalam Rangka Pencegahan Corona Virus Disease 2019 (COVID-19). Menteri Perhubungan Indonesia.

Romdiati, H., \& Noveria, M. (2006). Mobilitas Penduduk Antardaerah Dalam Rangka Tertib Pengendalian Migrasi Masuk Ke Jakarta. Jurnal Kependudukan Indonesia, 1328.

Sampurno, M. B., Kusumandyoko, T. C., \& Islam, M. A. (2020). Budaya Media Sosial, Edukasi Masyarakat, dan Pandemi COVID-19. SALAM; Jurnal Sosial \& Budaya Syari, 529-542.

Shuja, K. H., Aqeel, M., Jaffar, A., \& Ahmed, A. (2020). COVID-19 Pandemic and Impending Global Mental Health Implications. Psychiatria Danubina, 32-35.

Suryahadi, A., Izzati, R. A., \& Suryadarma, D. (2020). The Impact of COVID-19 Outbreak on Poverty; An Estimation for Indonesia. Jakarta: The SMERU Institute.

World Health Organization. (2011). Global status report on communicable diseases 2010. Italy: World Health Organization.

World Health Organization. (2020). Coronavirus Disease 2019 (COVID-19) Situation Report-10. World Health Organization.

Kompas. (2021, 09 Februari). PPKM Mikro Berlaku, Apa Bedanya dengan PPKM?. Retrieved from Kompas: https://www.kompas.com/tren/read/2021/02/09/060200565/ppkm-mikroberlaku-apa-bedanya-dengan-ppkm-?page=all (Diakses pada 16 Maret 2021).

VOI.ID. (2021, 07 Januari). Apa itu PPKM dan Bedanya dengan PSBB?. Retrieved from VOI.ID: https://voi.id/berita/25725/apa-itu-ppkm-dan-bedanya-dengan-psbb (Diakses pada 16 Maret 2021). 
Republika. (2021, 11 Februari). Kala Warga Bertanya, 'PPKM Mikro Itu Apa?'. Retrieved from Republika: https://www.republika.co.id/berita/qobozf409/kala-warga-bertanya-ppkm-mikroitu-apa-part1 (Diakses pada 16 Maret 2021).

Surat Keputusan Gubernur Sumatera Utara Nomor 188.44/125/KPTS/2021 tentang Penetapan Pemberlakuan Pembatasan Kegiatan Masyarakat Mikro di Kapubaten/Kota Provinsi Sumatera Utara Dalam Rangka Penanganan Corona Virus Dease 2019 (Covid-19). Pemerintah Provinsi Sumatera Utara, Medan.

Vredenbregt, Jacob. 1984. Metode dan Teknik Penelitian Masyarakat. Jakarta : PT. Gramedia. 